\title{
Towards the Configuration of an Industrial Engineering Education Field in Colombia from the Critical Didactics Pedagogy*
}

\author{
Luisa F. Rodriguez \\ Doctorado Interinstitucional en Educación, Universidad Distrital Francisco José de Caldas, Bogotá, Colombia \\ Email: luisafrv@gmail.com
}

Received 9 January 2014; revised 9 February 2014; accepted 19 February 2014

Copyright (C) 2014 by author and Scientific Research Publishing Inc. This work is licensed under the Creative Commons Attribution International License (CC BY). http://creativecommons.org/licenses/by/4.0/ (c) (i) Open Access

\begin{abstract}
This work I try to deliver in this paper due to the search by the sense of being a teacher-engineer, for some time. The constant search for the meaning of engineering education in environments like ours, still so dependent senses and knowledge of others, that being so alien, and imposes were simply assumed without further discussion. Industrial engineering does not arise in Colombia as a field of being able specific, with a corpus discipline clearly definitely and differentiated, which is constituted one of the motives that impedes his tracking inside engineering education history. In the statements till now opposing, there is glimpsed how this function was replaced by other engineers in the industry, such as chemical or mechanical engineers, maybe the only one fact that reveals his emergence is his institutionalization as study plan in the Universidad Industrial de Santander in 1958. The exhibition of these facts, it uses as support: The first one is that the processes of modernization and the form like formed, from the new forms of economic rationality created with the development model; they made necessary the appearance of the industrial engineering as discipline in the powers of engineering. The second one is that it is possible to form alternate speeches for the field of the industrial engineering in Colombia. This reflection becomes relevant in recent times when promoting critical thinking in engineering education has become important, from the understanding that engineering moves into the intersection between social and technical expertise should adapt to the economic, political and cultural contexts in which it is applied. To which I make use of Foucault's notions of power and subjectivity, the Bourdieu's notions of symbolic violence and Habermas communicative action. Finally I try to illustrate the reflection with the application of the concept "affectively critical learning" developed from the courses that I directed in the Universidad Autónoma de Colombia.
\end{abstract}

\section{Keywords}

Industrial Engineering Education; Bourdieu's Notions of Field and Symbolic Violence; Foucault's

*Outcome of doctoral thesis co-supervised for l’École Doctorale CLESCO UMR-EFTS de l’Université de Toulouse II-Le Mirail, France. 


\section{Introduction}

As (Mayor, 1989) reports, Alejandro Lópezwas who on having founded the chair of Industrial Economy in 1912 in the Escuela Nacionalde Minas de Medellin for the engineers in the last year of formation, (looking for the conditions of the most efficient organization of the companies), inculcated the principles of Taylor and Fayol into his students, turning into the most remote precedent that it had brings over of a comparable industrial engineer formation.

Later, with the accession of the capitalism and the industrial strengthening that gave beginning to the production in mass and determined the need to adopt new forms of rationalization of the work, from the implantation of the development model, about 1950; an untimely managerial summit took place in Colombia that shot the demand for education in these areas, and motivated a new social division of the work.

In 1958 with the accomplishment of the first seminar of Scientific Administration, there is created the Instituto Colombiano de Administración-INCOLDA — that gave like proved the creation of the Career of Industrial Administration of the Faculty of Mines, now it annexes to the Universidad Nacional sectional of Medellin. In the same year, one believes the first faculty with the name of Industrial Engineering in the Universidad Industrial de Santander (UIS), the teachers were coming from the careers of Chemistry and Chemical Engineering of the Universidad Nacional de Colombia, of the foreigner and engineers gone away from the Escuela Nacionalde Minas. In 1960 was created in Medellin the Escuela de Administración, Finanzasy Technología-EAFIT—and there is established the career of Industrial Engineering in the Universidad de los Andes. Hereby, the university device of the country was adjusting to the requirements of the industry, which was coming applying the principles of work rationalization: the trades description, times and movements of the work, the cost measure is necessary of every operation and establishment of work standards and production incentives.

During the 70s years, as a result of the United Nations for the Development PNUD technical cooperation project, that which sought to direct top education to the occupational and technical thing as base of the economic growth, the increase arises for the demand of careers that are relatives with the administration of the industrial technology (specialized engineering), since it was the case of the industrial engineering, with the administration and "rationalization" of the State's economy and of the private company (economy and relatives disciplines) searching of answers to the social demand for education and for solution of the social problems derived from the new form of economic growth.

The processes of rationalization that gave origin to the industrial engineering in Colombia and then those of diversification that have marked his transformation, allow to demonstrate the difficulties in the configuration of a knowledge field, clearly differentiated from other engineering and still of other disciplines as management administration or the economy, and justify asking if it is possible to think in the consolidation process of industrial engineering as a field of knowing in Colombia?

Current events like the Reform to the Law 30 of Higher Education and the incursion in the Free Trade Agreement, make think about the type of formation that we want for our industrial engineers, from the reproduction of the models obtained from the industrialized world, or from alternate speeches, result of reflection and knowledge the structures that are behind the configuration processes of discipline and that they will carry his consolidation, or perpetuating his dependence. This paper aims to contribute to understanding the role of the industrial engineer in the economic and social context of the country, and wonder if an "other speech" Industrial Engineers in Colombia, outside the hegemonic discourse scrounged from the first world, is possible .

\section{Methodology}

\subsection{Industrial Engineering as a Field of Knowledge}

Thus, the starting point for this work was the formulation of the following questions: Can we affirm that the process of modernization led to the configuration of industrial engineering field in Colombia? And to that extent, what conditions would be possible to think of an alternative discourse of resistance to the modernization process assumptions on which the field was set? 
Bourdieu's field theory contributed theoretical substratum from which there are analyzed the diverse tensions that gave origin to the discipline, likewise, the notions on subjectivity of Foucault, while, with the restoration of the development speech, the educational expansion, the urbanism and the industrialization during the consolidation of the modernization, in the second half of the 20th century in the country, were imposed and appropriate new speeches and fields of knowing, as that industrial engineering.

The conformation of the social specific fields of every discipline of knowing or profession, as that of the industrial engineering they serve to realize of the degree of inculcation or permanence of a specific habitus, produced in the disciplinary processes of reproduction, carried out in the social university space. Or saying of another form, the conditions and characteristics that favor the emergence of the processes of reproduction, for the speeches that it creates, turn also into the possibility conditions of the discipliner social field.

One of the decisive events in the structure of these new discursive objects, constituted it the appearance of the modernity notion in the moment itself of capitalism consolidation and the appearance of technology notion in the economic field, Weber for example, who emphasizes the value of technology in exaltation of the capitalist spirit in Europe at ends of 19th century, whereas Marx defines the process of simple accumulation as condition of existence the capitalism that characterized the modern world. And Touraine for whom the instrumental rationality bases of the capitalism, which defined the industrial companies, is sustained in the technology, which began to the fret with the objective rationality of the sciences.

Other studies like (Vásquez, 2007) make a Foucault’s analysis of the archaeology offer that on having delimited the margins, the edges, the excluded from the speech, which the history has not used, allows to see the fissures and the problems in the constitution of the human sciences and reveling his instrumental rationality as offer of illustration and as practice of slavery. This rationality carries Foucault to placing the conformation of the subjects in the power/know dispositive, in the technologies of domination and in a detailed consideration of the modern individual as product of a multiplicity of dividing and individualizer technologies, of subordinationsubjectivity, questions traditionally ignored by the macro theoretical perspective of the social critical science.

This study raises also that the Foucault's analysis, it allows to contrast like in the study of Habermas's communicative action, there exists a devaluation of decisive elements for the analysis of the modern relations of power, that surely Habermas, in reason of his loyalties to the theories of Austin and Searle's "speech-act", attributes to them a character idealistic and neutral in excess, disregarding the effect of the bodies administration in the modern society relations power, when this might constitute an enrichment of perspective to the communication theories.

\subsection{Affectively Critical Learning (ACL)}

The construction of alternate possible speeches in the pedagogic practice with the engineering students was approached from Habermas (McCarthy, 1987), who suggests how from the communicative rationality unlike the merely instrumental rationality, through what subject leaves the individual sphere and placing action in the cooperation with other subjects. According to this vision, the actors moved by the communicative action, do not chase the attainment of a selfish end but they aspire to be coordinated across acts of understanding, called in this text "affective interactions" that assure the subjects, by means of actions of mutual affectation, of affection, should come out the univocal nature towards a world ruled by interpretive and symbolic order language. These affective interactions are formed from the recognition of the lacks that has the subject who demands affection of others, but also from the recognition of the lacks and differences that have the others, realized for this subject plaintiff of affection.

The self-seeker objective of using Foucault and Habermas at the same time inside the present offer, is an approach to (Díaz, 1993) work, about intellectual education field in Colombia, who using the observation of changes and breaks in the exposition of the speeches so much instrumental as regulative of the educational field in Colombia, it manages realize of the theoretical trends and practices suffered by the above mentioned field, as well as also it allows to demonstrate alternative possible speeches.

From this search, to recognize the pedagogy trends of type techno-instrumental, humanist-conservative, managerial and the pedagogic for the control, which projects of formation tend viable the adjustment, the integration and the social mobility, from the logic of inequality compensation and able of container conflicts for a few subjects that are claimed be "assisted, integrated and built-in" (Ortega, 2009). Pedagogies that are supported from speeches anchored in the quality, competitions, standards; tolerance speeches, fundamentalism, skepticism 
and ethical relativism. The "Affectively Critical Learning” (ACL), result of real and conscious affective interactions, is proposed as an "alternative expression for the resistance, indignation, affirmation and commitment of teachers, students and researchers towards building links from social differences and inequalities."

Because as (Freire, 2006) said: "one of the primary tasks of critical pedagogy (...) is to defend a teaching practice in which the rigorous teaching of content never becomes cold, mechanical and falsely neutral manner." The opt in teaching, by speeches from the difference, approached from the assumed conditions of inequality and exclusion, completely away from the visions that promote conformity, helplessness and resignation, and validate an entire subordinate policy as acceptable. A learning taken from the dialogic praxis with the excluded, other cultures, with different historical and social practices with different forms of subjectivity, is reflective practices that value potentials, needs and deepest desires of those other cultural expressions. They become desirable objectives in the education of engineers.

\section{Resultants}

The existence condition for a knowledge field is the formation of a discipline habitus, as a result of learning processes but in terms of groups, communities agree through understanding acts, and not individually, i.e. mutual involvement between the environment and the subject, called herein "affective interactions". Giving the need of tending an education towards building links from social differences and inequalities that does not disregarding the bodies administration effect in the power relations of modern society, in teaching practice arises the proposal of "Affectively Critical Learning" (ACL) from the application of various teaching resources, displayed below:

It this way during the second half of 2012 was began this process of experimentation with students, obtaining quite enlightening results about how they assume or otherwise evade the search for affective interactions in the social subject's construction identities and within their learning processes. Experience conducted by the author in all courses, some of which were very instrumental: as Production Costs course for business managers students, others courses, I took the opportunity to expand the content like an elective course: Discipline and Technology, Industrial Engineering Introduction and Basic Business Management with industrial engineering's students, through readings and documentaries about the development model and modernization that originated engineering in Colombia, parallel to the thematic content of each discipline was achieved a process of sensitization in most students.

Subsequently, these groups began to take their own positions on the various issues of the subjects. So it was during this stage, different groups in all courses, with the help of various resources such as videos or games, it did very thorough analysis of various aspects and phenomena of economic and political crisis in society, such as the extractive, outsourcing costs , consumerism and lack of sustainability in engineering projects.

There were such interesting topics as the group responsible for analyzing the "business thinking" in the course of Basic Business Management, he used two documentaries, one, "The Story of Stuff" to put into question the role of industry and employer in production systems. And the other, some excerpts from the "Forbidden Education", make a challenge to the logic of the modern school, based on the principles of mass production, as responsible for all modern western thought, so far from the target paramount that should prevail in all types of education: "The development of a comprehensive education centered on love, respect, freedom and learning". "Development of worth and inalienable rescue difficult challenge of an ever-playful education that does not require the teacher to become a clown rather involves implementing the pedagogical benefits of the notion of complex and serious game-" (Cubillos, 2012).

Following this proposal, use of these documentaries in all courses to motivate various analyzes, one of which took the Costs students course, to incorporate the concept of "outsourcing production costs" became, until the time was not taken into account in the study of manufacturing product costs formation, highlighting the estrangement between the theory taught in the classroom and reality.

Discussions also got into the courses, about the problem issues raised in the documental. There is polarization between groups was still very chained with control pedagogies in, rooted paternalistic figure of "Professor Smarty" validating reward and punishment, as forms of "evaluation" founded on fear. And others trying to take more liberal positions, but with much fear and anxiety, feeling that it was probably the only place where "they were allowed to" express themselves that way.

During the year there was too, various documentary sources delivered by students in different class discus- 
sions; which were redistributed as research resources in other courses arrived. Thus, Quimbo Huila situation was analyzed after the eviction promoted by the central government for the construction of a dam with the same name in August 2012, in Business Management, Introduction to Industrial Engineering and Production, was raised as a problem of environmental management and sustainability of such projects, in the Costs course questioned the social cost-benefit of this type of business factor analyzed. And Elective Discipline and Technology was approached from the social, environmental and governance issues generated from the extractives process, as part of complex systems analysis whose dynamics is not necessary to mitigate and contain less, but rather, to take sides, from critical positions. In this sense, another important resource that emerged in the analysis to the different subjects was the movie "The Corporation".

As a final step in the courses, was scheduled a project that integrate the topics covered in class from a social perspective and sustainability. At this stage it was very satisfying to find good proposals from urban agriculture projects, social management with communities in both formal and informal vendors from different Candelabra's areas in Bogota, defense and protection of the public space, since the students' lives histories and their grandparents, displaced rural relatives, neighbors and business traders, also through interviews with workers and employees of the University. Some students discussed the work of the mayoralty institutions from different points of view its actors of.

\section{Analysis and Conclusions}

It is true that the creation of specific social fields in each knowledge discipline or profession, such as industrial engineering is the result of the inculcation degree or durability of a specific habitus, produced in the disciplining process of reproduction, carried out in the university social space. It is also true that these fields are the result of learning processes at group level, not at the individual, communities agree through acts of understanding, called herein "Affectively Critical Learning (ACL)", as an alternative expression for resistance, indignation, affirmation and commitment of teachers, students and researchers towards building links from social differences and inequalities.

The discursive object of economic growth and development is supported on the same principles of economic rationality that led to the emergence of industrial engineering as a knowing discipline. To why they are on existence conditions and processes of subjectivity by agents' field, such statements become its possibility condition.

But on the other hand if the possibility condition of the industrial engineering field as a knowledge discipline is the possibility of building subjects in the limited domain of development discourse, there is also the possibility of enhancing subject to limited resistance to that domain. And the question would be "how to resist?", if one side is already very clear that economic growth theories are in crisis by ignoring who the development directly affected to, is not sufficient simply to engage them now, but to rethink the proper objects of enunciation: The principles of efficiency and economic production, are they really productive? What is to been productive, and to whom, at one time and at another not?

"The problem of adopting a purely strategic approach is that it runs the risk of falling into what could be characterized as a mercenary engineering sense, i.e., one from which engineers use wisely or perhaps slyly their judgment to make the best decisions of system design to an end which is engaged by the highest bidder, without asking for an end in itself” (Mejía, 2009). This type of proposal as promoting Affectively Critical Learning (ACL) would be quite convenient. Taking advantage of this scheme, it can be said that a critical engineer, first identifies both customers, purposes, normative assumptions and general concepts that manifest in different engineering designs, such as those that do not manifest there and have therefore been excluded.

Perhaps, although it is desirable from a pedagogical point of view that students develop a certain capacities to regulate their own learning, as deduced from the postulates proposed by international agencies, is also true, as exposed (Mejía, 2012) that "limit this educational ideal of the relationship of an individual with its activity cannot be less than risky, because it is a type of self -centered means to an end, which makes us vulnerable from attempts of manipulation by large traders to meet their demands for system performance”. This type of learning that "not put into consideration the different constructions of meaning that can emerge in the same situation, but is focused in one direction guided by efficiency and effectiveness 'makes' our way of life forever are determined by others, and can never be free indeed".

Thus thinking of an "Another University" or the Alternative University proposed by the communities of Chocó Network Communities in Resistance since 2003 also formed by indigenous, negro and peasant communi- 
ties in which sharing knowledge is generated in resistance, whose view point to the conception of a new reality, an alternative imagination, seeking to create a new state, a society or non-consumer capitalism, a society based on solidarity and the right of peoples could be possible.

\section{References}

Cubillos, J. (2012). La educación prohibida. El expectador. http://www.elespectador.com/opinion/columna-370346-educacion-prohibida

Díaz, M. (1993). El Campo Intelectual de la Educación en Colombia. Cali: Universidad del Valle.

Freire, P. (2006). Pedagogía de la indignación (pp. 53-54). Madrid: Ediciones Morata.

Mayor, A. (1989). Ética, trabajo y productividad en Antioquia: una interpretación sociológica sobre la influencia de la Escuela Nacional de Minas en la vida, costumbres e industrialización regionales. Bogotá: Tercer Mundo Editores.

McCarthy, T. (1987). La teoría crítica de Jürgen Habermas (p. 449). Madrid: Tecnos.

Mejía, A. et ál. (2012) La autonomía como propósito educativo. De qué estamos hablando? CIFE Ponencias. http://cife.uniandes.edu.co/images/PonenciasPE/la_autonomia_como_proposito_educativo.pdf

Mejía, A. (2009). Tres esferas de acción del pensamiento crítico en ingeniería. Revista Iberoamericana de Educación. Organización de Estados Iberoamericanos para la Educación, la Ciencia y la Cultura (OEI) (pp. 5-6).

Ortega, P. et al. (2009). Sujetos y prácticas de las pedagogías críticas (p. 11). Bogotá, Colombia: Editorial El Buho.

Vásquez, A. (2007). Habermas; el discurso filosófico de la modernidad y la crítica a Foucault. En Revista de Ciencias Sociales, Facultad de Derecho, Universidad de Valparaíso. 